Peer-Reviewed Article

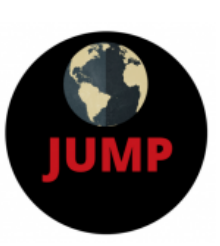

OJㅡㄹ

(C) Journal of Underrepresented and Minority Progress Volume 5, Issue 2 (2021), pp. 125-144 ISSN: 2574-3465 Print/ 2574-3481 Online http://ojed.org/jump

\title{
Examining the Relationship Between HBCU Faculty Online Education, Innovativeness, and Attitudes Toward Computers
}

\author{
Valerie Riggs \\ Krishna Bista \\ Christian Anderson \\ Morgan State University, USA
}

\begin{abstract}
Historically black colleges and universities (HBCUs) are the most famous institutions of higher educations for minority students in the United States. Online education has drawn attention to HBCUs because of demographic and social shifts, student needs, and global conversations in academia. In addition, the recent COVID-19 pandemic has pressured faculty to move their courses to online or remote teaching formats. This article examines whether significant relationships exist among the variables: levels of innovativeness, attitudes toward online education, attitudes toward computers, and various demographic characteristics of full-time and part-time faculty members employed at one HBCU. Based on 110 participants, results indicated a significant relationship between online teaching innovation and faculty attitude toward computers.
\end{abstract}

Keywords: academia, attitudes towards computer, COVID-19, higher education, $\mathrm{HBCU}$, online teaching, survey research 


\section{INTRODUCTION}

Throughout the past decade, many Historically Black Colleges and Universities (HBCUs) continued to encounter financial issues because of varying governmental policies, falling enrollment, low recruitment and retention efforts, as well as inadequate technology infrastructures and support services (Nealy, 2009). The continuous development of online education courses is one way in which HBCUs can work toward increasing revenue, resulting in access to a larger market share of students, improved retention, and staying competitive with PWIs. Beasley (2014) reported that 33 HBCUs offered online programs in 2014, where 26 of them were at public HBCUs, and seven were at private HBCUs. Past studies indicate that HBCUs are not developing online education courses and programs at the same rate as Predominately White Institutions (PWIs) (Nealy, 2009; Stuart \& Yep, 2012).

This lack of participation in this critical technology era could financially threaten HBCUs' survival in the future (The National Center for Education Statistics, 2017; Snipes, Ellis, \& Thomas, 2006). HBCU administrators may wonder why the development of these offerings is so low and inconsistent among HBCU institutions. Although institutional missions play a crucial role in developing initiatives, ultimately, faculty members are the driving force in creating courses.

This study examined the relationships between (a) faculty attitudes toward online education and their attitudes toward computers and (b) levels of innovativeness and faculty attitudes toward online education. The research also explored whether gender, race, age and discipline, academic rank, experience teaching online, and years of teaching have any relationships with these variables. This study answered the following research questions:

1. What is HBCU faculty members' level of innovativeness in online education?

2. What are HBCU faculty members' attitudes toward online education?

3. What is the relationship between HBCU faculty members' levels of innovativeness and attitudes toward online education?

4. What is the relationship between HBCU faculty members' attitudes toward computers and online education? 


\section{LITERATURE REVIEW}

\section{Diffusion of Innovation Theory}

This study used the "Diffusion of Innovation" (Rogers, 2003. This theory presents innovations, such as technology, are more accepted based on the type of innovation, communication channels, time, and the social system. Figure 1 summarizes the communication channels that new ideas or technology move through as organizations or individuals determine whether to adopt or reject.

\section{Figure 1}

Communication Channels (Rogers, 2003, p. 171)

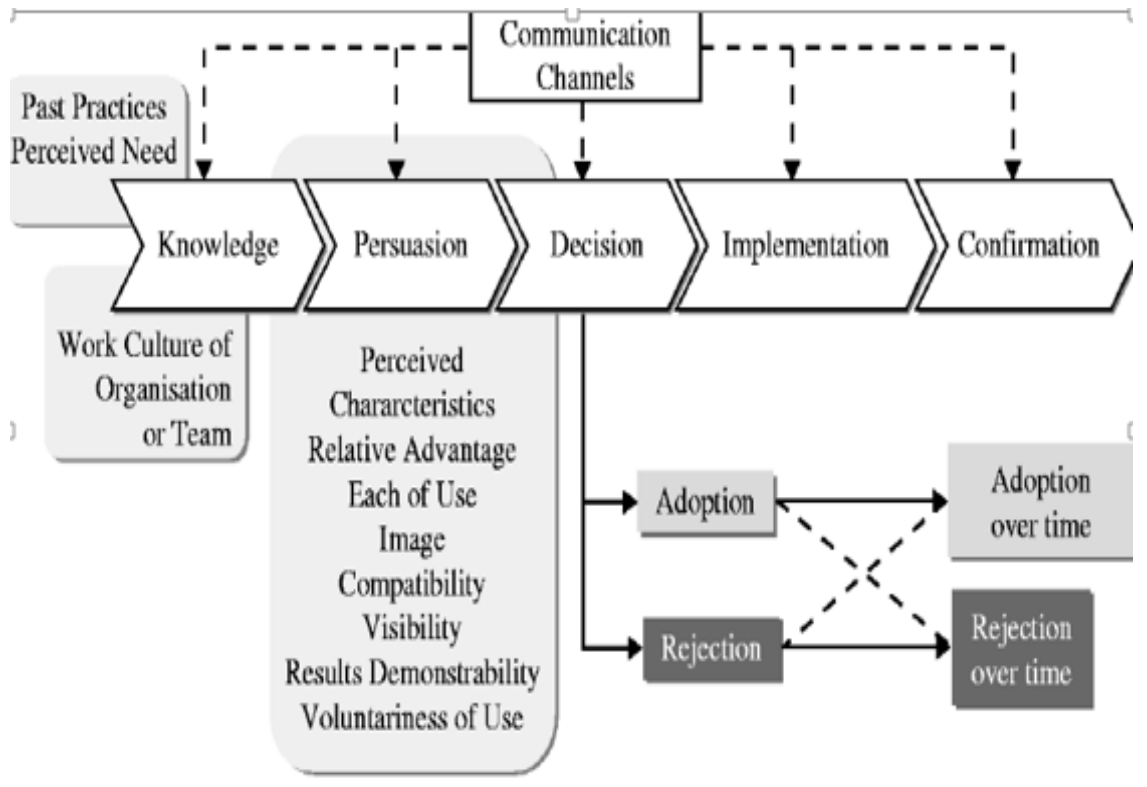

First, Rogers (2003) provides background information on how an innovation such as online education may move through communication channels and be accepted by faculty members. This theory informs this project in several ways. Rogers (2003) explains the step of persuasion in his approach where people develop positive or negative attitudes toward innovations during this step. Rogers (2003) found it essential to explore the attitudes on innovation and why some are persuaded faster than others. In this study, the innovation is online education. 
Second, Rogers' (2003) theory involves five categories of innovativeness faculty members may fall into as they consider adopting new technology. This is particularly important because as faculty members move through their experiences with new technology, they will eventually reach the next category and consequently the technology adaptation, resulting in the continuous move through the communication channel. Rogers (2003) described the first and highest category as Innovator. Innovators are people who want to be the first to try out the innovation. The second category is Early Adopters. Early Adopters are usually in leadership and are open to changing ideas. The third category is the Early Majority. The Early Majority are generally not leaders, but they will adapt to new ideas before the average person adapts to the same idea. The fourth category is the Late Majority. This category of people are skeptical of change and tend to be slow with adopting an innovation. The fifth and lowest category is Laggards. Laggards are very traditional and conservative. They are skeptical of change in general, and it is tough to win them over to try an innovation (Rogers, 2003).

\section{Online Teaching at HBCUs}

Decreased enrollment and attrition, competitive technology, equitable access, reliance on government funding, completion rates, and conservative cultures have been identified as threats to the survival of HBCUs. Several of these threats could be reduced by the continued development of online programming (Nealy, 2009). Consequently, exploring the threat of keeping abreast of innovative technology is relevant to this research study because it is essential to understand the impact of current struggles HBCUs have with advancing technology, infrastructure, and support in faculty members' development of online courses (Nealy, 2009; Hodge-Clark \& Daniel, 2014).

Studies have shown that positive attitudes of faculty toward technology have contributed to higher levels of computer skills, to the ability to teach online, the openness to accept university training, and feeling more freedom of personal expression (Broussard \& Wilson, 2018; Glass 2017; Johnson, 2015; Pereira \& Wahi, 2017). These studies suggested that faculty members with high levels of computer skills were more likely to teach online.

Recent research explores levels of innovativeness and their relationship to the use of online learning technologies and attitudes toward computers. To date, most of such research has been conducted at PWIs. Only a few studies were conducted at HBCUs (Lawrence, 2008; Keesee \& Shepard, 2011; Johnson, 2008). Nealy (2009) discussed that lack of participation in online education could financially threaten HBCUs' survival in the future. 
Surendra (2001) used Rogers' (2003) framework to predict the adaptation of web technology by faculty members and administrators at a university. The level of technology access and the amount of professional development were strong predictors of adopting innovations. Consequently, it is necessary to continue researching how HBCUs participate in online technology to determine best practices for the future.

\section{Online Course Development at HBCUs}

Several ideas have been discussed to understand the lack of development of online courses and programs within HBCU institutions. Flowers, White, Raynor, and Bhattacharya (2012) found that much of the issue resulted from institution size, cost of programming, and the scope of development of online programs. Arroyo (2014) reported that university faculty members and university presidents thought HBCU distinctiveness or tradition could be upset with the increased development of online courses, which could negatively impact the face-to-face faculty and student relationships, robust on-campus life, and traditional pomp and circumstance for which HBCUs are known (Harkness, 2015). Lorenzetti (2009) discussed the digital divide and how its impact may affect how HBCUs and their faculty members participate in online teaching and learning.

HBCUs have also encouraged faculty researchers to explore other models of online education such as open access courses that can help universities expand their offerings and accept more non-traditional students (Samayoa et al., 2016). Concerns remain about collaborating with third-party vendors, financial impact, and student-teacher interactions (Harkness, 2015). HBCUs that offer online programs are experiencing success and continued program development when accepted by the institution and faculty members developing and teaching the courses (Harkness, 2015). Consequently, the question becomes whether correlating factors contribute to faculty members at some HBCU institutions being more accepting of online programs and, as a result, spurring program development at a faster speed.

\section{Current Online Education Needs}

The literature reflects much discussion and many calls for HBCUs to make every effort to compete in the online education market and to embrace the opportunity (Smith, 2011; Sturgis, 2012). The discussions show disdain toward the increasing traditional HBCU market share absorbed by for-profit institutions and PWIs with competitive online offerings. In one instance, it was discussed that large for-profit entities, such as the University of Phoenix, spent $\$ 222$ million on marketing their online offerings. In general, HBCUs do 
not have the financial revenue to counter such marketing. The recent COVID19 pandemic shed further light on HBCUs' struggles as learning formats changed quickly from traditional in-person to online learning (Galvin, 2021). Nonetheless, the tradition and support of HBCUs remain strong, and the opportunity exists to maintain, regain, and stay competitive (Beasley, 2014).

Pre-pandemic, HBCU administrators began to consider the need and opportunity for institutions to enter into online learning (Sturgis, 2012; Samayoa et al., 2016; Waymer \& Street, 2016). Minority serving institutions reviewed online learning and considered it an option as more and more students turned toward enrollment in online schools and programs. Several HBCUs turned toward non-traditional students and are focused on strengthening their enrollment through online offerings. Hampton University Online has had success with online enrollment and had about 400 students in 2012. Hampton was the first HBCU to offer online degrees (Sturgis, 2012). In addition, there are several online initiatives sponsored by influential HBCU alumni, such as national radio personality Tom Joyner, who have jumped on the trend of supporting the development of online programs at minority institutions. Although several institutions have joined in the trend in the development, there is still hesitancy about its success and the economic, political, and social impacts of such a drastic change in this aspect of learning (Sturgis, 2012).

The sudden academic operational shifts during the COVID 19 pandemic unveiled the technology struggles that many HBCUs experienced. Institutions who were previously hesitant or debating whether and how to allocate technology funds towards online education immediately had no other options. This also shed light on the inequities that continued to exist within minority serving institutions (Galvin, 2021).

\section{Faculty Attitudes toward Online Education and Technology}

The literature shows both negative and positive attitudes toward online learning. Negative attitudes may have resulted from the lack of computer skills, workload, and university support (Chen, 2009; Grossman \& Johnson, 2015; Glass, 2017; Mitchell \& Geva-May, 2009; Pereira \& Wahi, 2017).

In addition to experience and computer skills, negative attitudes toward online education were often associated with department affiliation. Pereira and Wahi (2017) found that faculty in nursing, business administration, English, industrial technology, and other interdisciplinary studies departments were likely to have less positive attitudes toward online 
education and, consequently, needed more support from their administrators and universities. Further, Pereira and Wahi (20170 found that there was variance in attitude toward online education with less positive attitudes from tenured faculty members, had higher rank or infrequently used online education technology. It was also reported that they were more likely to have less than positive attitudes and self-efficacy toward technology and computers (Pereira \& Wahi, 2017).

\section{Faculty Attitudes toward Computers and Technology}

Several studies have measured faculty members' attitudes toward the adoption of online education (Al-alak \& Alnawas, 2011; Bourrie \& Sankar, 2016) It is found that computer experience and positive attitudes toward computers were the strongest indicators of behavioral intentions. Bourrie and Sankar (2016) found that attitudes toward computer-related technology were impacted positively by how easy the technology innovations were to use. The determination by faculty members of ease of use was directly related to the intention to adopt the computer technology. They also found that faculty members who cared about their student learning outcomes were more likely to use new computer technologies. Poor attitudes toward computer technologies resulted from the faculty member having a lack of time, proper training, intrinsic motivation, and lack of technical skills. It is concluded that easy-to-use computer technologies contribute to more positive attitudes toward computers. Padmavathi (2016) performed a correlational study of 110 student teachers' readiness to use computers in teaching. This research suggested that attitude in conjunction with training and experience in using computers leads to computers. It was found that teachers who had years of computer experience were more likely to have a positive attitude toward computers.

Previous research at Primary White Institutions has shown that faculty attitudes towards computers and technology were related to technology use. HBCUs have lagged with innovations such as teaching online. Not much research is available that explores this phenomenon. Likewise, there is a growing call from HBCUs to understand these various relationships. This research study aims to examine whether relationships exist between HBCU faculty and their (a) attitudes toward online education and attitudes toward computers and (b) levels of innovativeness and attitudes toward online education. The research also explores whether demographic variables at HBCUs have an impact on attitudes towards computers, technology, and innovations such as teaching online. 


\section{RESEARCH METHOD}

This study used a cross-sectional survey method to collect quantitative data from the faculty participants to determine whether a relationship existed across categories. A convenience sample of 110 participants was obtained from two HBCU institutions. In data analysis, several variables such as gender, ethnicity, age, faculty rank, experience in teaching online, and length of teaching were included.

Data were collected from an online survey. The survey included questions related to (a) Faculty Attitudes Toward E-Learning, (Mishra \& Panda, 2007), (b) the Teacher Attitudes Toward Computers Scale (TCAS), attitudes toward computers, and (c) the Measurement of Innovativeness (Hurt, Joseph \& Cook, 1977). Out of 554 participants who received the questionnaire electronically, 110 participants completed it $(20 \%$ response rate). A one-way test of variance (ANOVA) and a t-test were used to determine significant relationships among variables.

\section{RESULTS}

\section{Demographic Characteristics}

One hundred and ten faculty members responded to an emailed survey for this research. Sixty seven (59\%) faculty members were from Arts, Education, Humanities, Social Sciences, and other departments. Forty-three (40\%) faculty members responded from Business, Science, Technology, Engineering, and Mathematics (STEM) departments. Data on whether a faculty member had ever taught a fully online or partially online (hybrid) course using a Learning Management System revealed that 67 (60.9\%) faculty members had taught online.

There were fifteen $(13.6 \%)$ faculty members who have had the rank of Professor. Twenty-five (22.7\%) faculty members held the rank of Associate Professor. Thirty-four (30.9\%) held the rank of Assistant Professor, and $36(32.7 \%)$ had the rank of Lecturer or Adjunct. There were more Lecturer or Adjunct faculty members in the sample. Approximately $70 \%$ of the participants were between 38-61 years old.

Similarly, 31 out of 110 (28.2\%) faculty were White or Caucasian, $64(58.2 \%)$ were Black or African American, and $15(13.6 \%)$ identified as another race. There were 43 (39.1\%) males and 67 (60.9\%) females. Among the participants, $14(12.7 \%)$ faculty members were teaching for $0-5$ years, 19 $(17.3 \%)$ faculty members for 6-11 years, and $72(70 \%)$ of faculty members were teaching for 12 years or more. 


\section{HBCU Faculty Members' Levels of Innovativeness}

This study used Rogers' (2003) five categories of levels of innovativeness to classify the data. Table 1 shows that $66.4 \%$ or 73 of the 110 faculty members were classified as Early Majority and $33.6 \%$ or 37 were Early Adopters. None of the respondents were identified as Innovators, Late Majority or Laggards. It is important to note that more than one-third of the respondents in this study consisted of adjunct faculty or lecturers, which are at the lowest level of academic rank. Limitations to the study may be that the composition of the sample influenced the outcome of the study related to the first research question, which explored faculty levels of innovativeness in online education. The results may indicate lower rank faculty members are more willing to be exploratory, and varying factors could contribute to this. Lower ranked faculty members may be younger and maybe just starting their careers. They may have varying educational pursuits, which may include completing their next degree. They also may have different employment goals, which could range from working part-time or pursuing a higher rank position at their university. These descriptors may allow them to have more time or increased motivations to perform, leading them to being more open to online learning.

The demographics of faculty members in this study were categorized by discipline, online teaching experience, rank, age, race, gender, and overall years of teaching. Faculty member disciplines were reported in five categories. Data show faculty members fell into either the Early Adopter or Early Majority categories. The majority of faculty reported as Early Majority across all disciplines. This is significant because an assumption may be that if there is low participation in teaching online that this may be related to lower levels of innovation. In this case, faculty members at this university were more likely to adapt to innovations.

Faculty members identified whether they had ever taught on line in two categories. Results showed 67 out of the 110 -faculty surveyed had taught online. Twenty five percent (25\%) of those faculty were Early Adopters while seventy five percent (75\%) were Early Majority. Forty three out of the 110 faculty members surveyed had not taught online. Forty six percent $(46 \%)$ of those faculty were Early Adopters and fifty three percent (53\%) were Early Majority (See Table 1). Data on this demographic show most faculty member respondents had taught online and were Early Majority.

Faculty with the rank of Professor reported largely as Early Majority and then Early Adopters. Faculty with the rank of Associate Professor reported higher as Early Majority and then Early Adopters. Faculty with the 
rank of Assistant Professor reported higher as Early Majority and Early adopters. Lecturers/Adjuncts also reported higher as Early Majority and then Early Adopters. Of all faculty ranks, most identified as Early Majority.

Of the faculty in the age range of 26-37, thirty-six (36\%) were Early Adopters and sixty four percent (64\%) were Early Majority. Of the faculty members in the age range of $38-49$, twenty two percent $(22 \%)$ were Early Adopters and seventy-eight (78\%) faculty were Early Majority. Of the faculty members in the age range of 50-61 age range reported forty percent $(40 \%)$ were Early Adopters and sixty four percent (64\%) were Early Majority. Of the faculty members who were 62 and over thirty six percent $(36 \%)$ were Early Adopters while sixty three percent (63\%) were Early Majority (See Table 1). The highest number of respondents were between by age were 5061 and the highest number of respondents by level of innovativeness were Early Majority.

Faculty members' race was reported in three categories. Thirty nine percent $(39 \%)$ of Caucasian faculty reported as Early Adopters, and sixty one percent (61\%) were Early Majority. Twenty seven percent $(27 \%)$ of Black or African American faculty reported as Early Adopters while seventy three percent $(73 \%)$ were Early Majority. Faculty members from other races reported that fifty three percent (53\%) were Early Adopters and forty seven percent $(47 \%)$ were Early Majority. Findings on faculty members' race and innovativeness show the majority of respondents were Black or African American. White or Caucasian and Black or African American faculty members were mostly Early Majority. In contrast, other races reported being mostly Early Adopters.

Faculty members reported in two categories of gender. 37\% of males were Early Adopters and 63\% were Early Majority. Data on female faculty reported that 31\% were Early Adopters and 69\% were Early Majority. Findings on faculty members' gender show more females were respondents. However, percentages of female and male respondents were similar where more than $60 \%$ reported being Early Majority and an average of $30 \%$ or more reported being Early Adopter. Therefore, innovation levels were similar between genders.

Faculty members reported their years of teaching in three categories. Faculty that had been teaching for $0-5$ years reported that $36 \%$ were Early Adopters and $64 \%$ were Early Majority. Faculty that had been teaching for 6-11 years reported that 37\% were Early Adopter and 63\% were Early Majority. The majority of faculty reported they had been teaching 12 years or more of which 35\% were Early Adopters and 72\% were Early Majority (see 
Table 1). These findings show most respondents were seasoned teachers with more than 12 years of experience.

The majority of participants were from the arts, humanities and social science disciplines, where the majority were the Early Majority. Most early majority faculty members had taught online. Assistant professors and adjunct/lecturers were the most frequent rank with the majority of those being Early Majority. The most frequent age range for faculty members was 50-61. Black or African American race faculty members were the largest number of respondents as well as females. In general, the population was from this university is the Early Majority. Rogers's (2003) theory of innovation finds that Early Majority users, although not usually leaders, are more likely to adapt to new innovations. The findings from this research reflect that the faculty at this institution could be more likely to adapt new innovations such as teaching online.

\section{HBCU Faculty Members' Attitudes Toward Online Education}

A one-way analysis of variance (ANOVA) on attitudes toward online education by faculty members' rank tested for significance among-groups. This test compared means between variables with more than two groups. There was a significant effect of rank on attitude toward online education question number four at the $p<.05$ level for the three conditions $[F(3,106)$ $=2.893, p=0.039]$. Results indicated that faculty (professors, associate professors, and assistant professors) reported higher scores on online than the scores of lecturer/adjuncts. regarding their opinions of online teaching; $\mathrm{t}$ (108) $=-2.36, p=0.020$. The question asked whether online learning saves time and effort for teachers. Male responses were reported a mean score of 2.97, and based on the Likert scale where $2=$ Agree, males were on the lowest end of agree. In contrast, female responses scored a mean score of 3.55, and based on the Likert Scale where 3=Does Not Apply, females selected on the lower end of this option.

Consequently, males reported more positive scores than females, indicating online learning saved them time. There was a significant difference in scores from question seven for male $(M=2.25, S D=1.09)$ and female $(M=1.73, S D=0.86)$ conditions; $\mathrm{t}(74.720)=2.65, \mathrm{p}=0.010$. The question asked whether the participant felt intimidated by online learning. Male responses based on the Likert scale were 2=Agree. In contrast, female responses based on the Likert scale were 1=Strongly Agree. Consequently, females reported more positive scores indicating they were more intimidated than males by online learning. 


\section{Table 1:}

Faculty Demographic Information (Innovativeness Category Distribution by Discipline, Ever taught online, Faculty Rank, Age, Race, Gender and Years of Teaching) Discipline, Ever taught online, Faculty Rank, Age, Race,

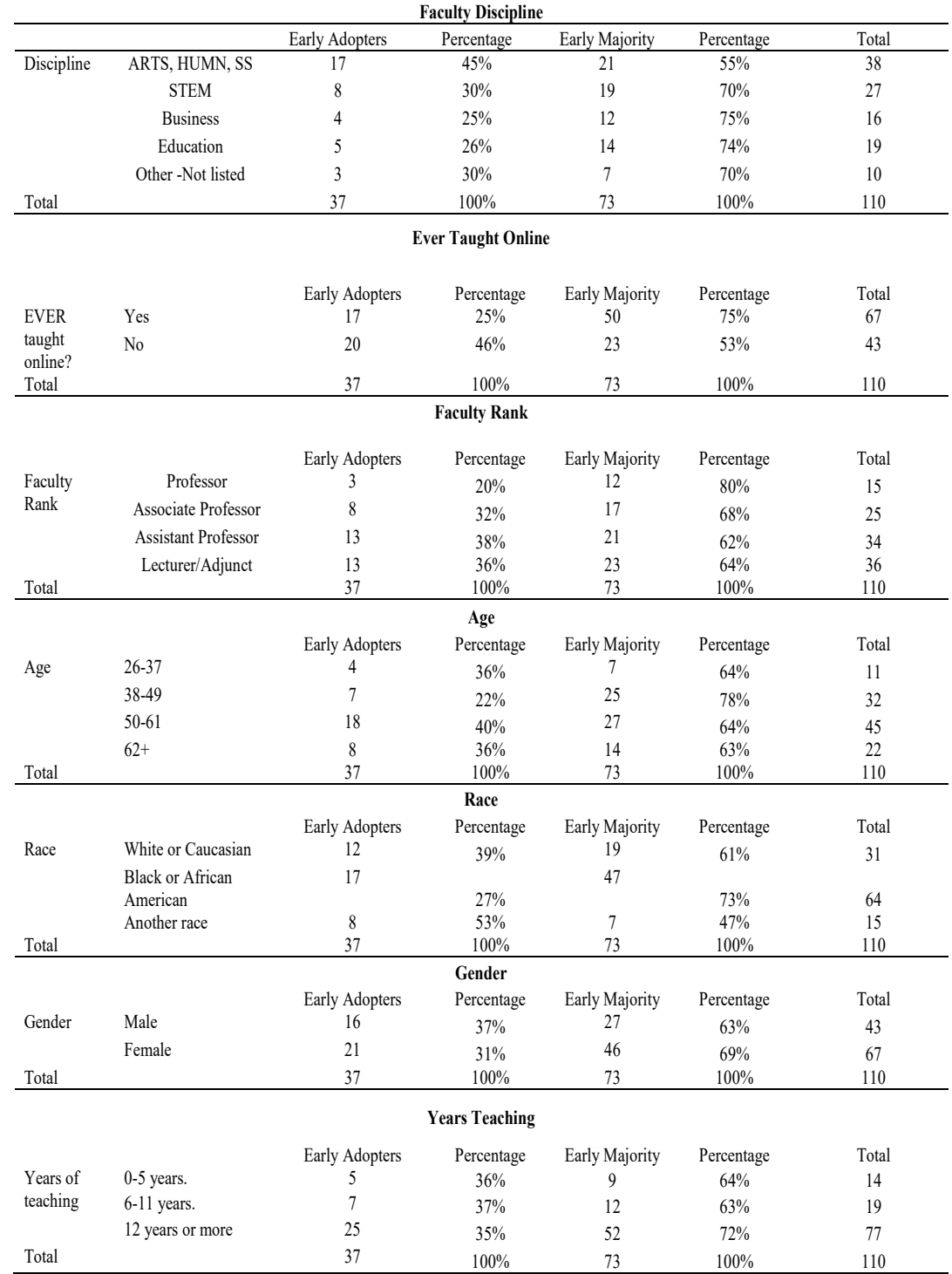


T-test analysis indicated that there was a significant difference between males $(M=2.97, S D=1.29)$ and females $(M=3.55, S D=1.20)$. There was a significant difference in the statement referring to whether the participant got a sinking feeling when they thought about using online courses. Question eight scores for male $(M=2.62, S D=1.23)$ and female $(M=1.91, S D=1.055)$ conditions; $t(79.469)=3.14, \mathrm{p}=0.002$. Male responses based on the Likert scale were on the higher end of 2=Agree, approaching disagree. Female responses based on the Likert scale were on the higher end of $1=$ Strongly Agree, approaching Agree. Consequently, females had more negative feelings about using online courses than males. There was a significant difference in the question nine scores for male $(M=2.76, S D=1.28)$ and female $(M=2.19, S D=1.15)$ conditions; $\mathrm{t}(108)=2.42, \mathrm{p}=0.017$. The question asked participants to decide whether online learning was effective for student learning. Consequently, females had more positive responses than males that online learning was effective for student learning.

The question asked whether online learning enhanced the pedagogic value of the course. Faculty members who had taught online majorly agreed based on Likert scale responses of $2=$ Agree. Faculty members who had not taught online selected Does Not Apply based on the Likert scale responses of 3. Their responses were on the higher end, approaching 4=Disagree. Consequently, faculty members who had taught online felt more positively than those who had not taught, that online learning enhanced their teaching.

A significant difference was found in the question seven scores for Yes $(M=4.32, S D=0.87)$ and No $(M=3.65, S D=1.02)$ conditions; $\mathrm{t}(108)=-3.70$ $\mathrm{p}=0.000$. The question asked whether online learning was intimidating. Faculty members who had taught online scored high with Likert scale responses of $4=$ Strongly disagree. Faculty members who had not taught online scored slightly lower and majorly selected Likert scale response of $3=$ Neutral. Faculty members who had taught online felt more strongly that online learning was not intimidating.

There was a significant difference in the question eight scores for Yes $(M=4.01, S D=1.13)$ and No $(M=3.48, S D=1.18)$ conditions; $t(108)=-2.33$, $p=0.021$ (See Table 16 and Table 17) The question asked whether they got a sinking feeling when teaching online or thinking about it. Faculty members who had taught online mostly agreed based on Likert scale responses of $2=$ Agree. Faculty members who had not taught online did not have sinking feelings. Consequently, faculty members who had taught online felt more negatively and had sinking feelings about teaching online or thinking about teaching online. 


\section{Levels of Innovativeness and Attitudes Toward Online Education}

The Pearson correlation coefficient was used to determine the relationship between two identified levels of innovation of HBCU faculty members: Early Adopters and Early Majority and their attitudes toward online education. There was a weak positive relationship between the two variables $(r=.284, p=.05)$. There is a significant relationship between Early Majority faculty members' levels of innovativeness and their attitudes toward online education. As the level of innovativeness increases, so do attitudes toward online education. In another word, Early Adaptors were likely to have positive attitudes toward online education.

Pearson correlation coefficient was used to determine the relationship between attitudes toward computers and attitudes toward online education. There was a weak positive relationship between attitudes toward online education and computers $(r=.380, p<.001)$ This means as attitudes toward computers increase so do positive attitudes toward online education. No relationship was observed between other demographic characteristics and attitudes toward computers.

\section{DISCUSSION AND CONCLUSIONS}

In this study, 37 participants (33.6\%) were self-identified as Early Adopters and 73 (66.4\%) or 73 were Early Majority, who according to Rogers are people who are usually in leadership positions and are open to changing ideas. Of the 110 participants, $61 \%$ had never taught online. Seventy-five percent $(75 \%)$ of the total number of respondents who had taught online were Early Majority who according to Rogers usually not leaders, but they will adapt to new ideas before the average person adapts to the same idea. Assistant professors had the highest level of Early Adopter innovation level (38\%) among all faculty members. Assistant professorship is the entry level position for tenure track faculty members, and consequently, these faculty members may be more open to new technology to support their goal of tenure (Poster, 2017).

In addition to tenure track motivations, age may also be a factor. In this research, races were categorized as African American, Caucasian, and Other Races. Faculty race and level of innovation showed those from Other Races are mostly Early Adopters. African American and Caucasians are mostly the Early Majority. However, Caucasians reported with higher levels of innovation than African Americans. Findings on gender reflected that 
males and female were equally categorized as Early Majority. Length of years teaching increased level of innovation. Faculty members who taught for over 12 years were in the Early Majority. Age is most likely a contributor to this as it can be assumed as the length of employment increases, so does age. Regardless, this is also positive news for HBCUs that most faculty members report innovativeness at the Early Majority level. Faculty members with Early Majority levels of innovativeness are more likely to adapt to new innovations. HBCUs can use this knowledge to explore best practices on making innovations such as teaching online more available to faculty members.

As results indicated, more than $50 \%$ of faculty members disagreed that online learning saved time, increased efficiency in teaching, improved communication, or enhanced pedagogy. In contrast, most agreed that online learning increased access to education and training, increased flexibility, was not intimidating or made them feel uncomfortable and was effective for student learning. These results show faculty members do see some merit in this teaching modality; however, they do see a conflict with how to incorporate teaching online based on time and pedagogical implementation.

Survey results also showed significant variations in the attitudes of faculty rank, gender, and whether the participants had ever taught online. It was reported that lecturers/adjuncts disagreed that online teaching increased flexibility, while all other faculty ranks agreed it did. Literature reports that negative attitudes were attributed to lack of computer skills, workload and lack of university support, and consequently supports the findings of this research study (Mitchell \& Geva-May, 2009; Chen, 2009; Grossman \& Johnson, 2015; Pereira \& Wahi, 2017; Glass, 2017). The findings from this research are similar to the literature in that faculty members with negative attitudes toward online learning do not know how to implement the technology required in online teaching, feel it is time-consuming, and feel intimidated.

Gender was found to be related to attitudes toward online education. Results indicated that females scored higher negative feelings about online learning than males. Females scored higher responses than males and found that online learning did not save time intimidated them. They also scored higher in response to negative feelings about using online technology and stated they were uncomfortable because of a lack of understanding of online learning. Male responses scored lower for all questions. Consequently, females had more attitudes towards online education.

Faculty members who had taught online reported higher scores than those who had not taught online when asked about whether online learning saved time, enhanced their teaching, and increased their efficiency. This is in 
line with the presumption that if a faculty member had taught online, they would be more favorable toward online learning. However, faculty members who had taught online reported feeling more intimidated about online learning than the scores reported for faculty members who had never taught online. This finding may suggest that universities that training for online course development and its associated technology is an important necessity. The literature references positive attitudes toward online learning were related to higher levels of computer skill, previous experience teaching online, university training, and the ability to maintain personal expression (Broussard et al., 2018; Glass 2017; Johnson, 2015; Pereira et al., 2017;). This study reports Early Adopters and Early Majority participants reported positive attitudes toward online learning, with some hesitation about time-saving, efficiency, and being intimidated.

Results indicated that levels of innovativeness are related to a faculty member's attitude toward online learning. The literature review reflected that attitudes toward online learning were related to computer skill, training and university support (Mitchell et al., 2009; Chen, 2009; Grossman \& Johnson, 2015; Pereira \& Wahi, 2017; Glass, 2017; Broussard \& Wilson, 2018). The findings suggested that Early Adopters would be less likely to be concerned with these issues, and Early Majority participants would be more likely to be worried. Faculty members' attitudes toward computers relate to their attitudes toward online education. This finding is consistent with the existing literature (Jiang et al., 2016). As faculty members' attitudes toward computers increase, so do their attitudes toward online education. No correlation was observed between other demographic characteristics and attitudes toward computers. Faculty members indicated that online learning was very time consuming and they did not know how to implement this practice. These findings may have been more positive if the computer skills of faculty members were increased. HBCUs can work toward continuous implementation of new training of computer software and online systems. This would assist faculty members with developing the skills necessary to reduce time to create online courses because there would be a higher level of comfortability with the tools. Further, increasing computer skills may lead to a more positive attitude toward computers and more positive attitudes toward online learning.

The implication of this study should be examined in the context of its limitations. As a result of the COVID-19 pandemic, the majority of faculty members at HBCUs and PWIs were required to teach online or remote classes. Although the findings are exciting and offer some directions towards online teaching, data were collected before the pandemic from a small sample from one HBCU. Many participating faculty members never taught online 
classes or there was no need to teach online classes in their departments. Future studies should explore faculty attitudes towards innovation after the COVID 19 pandemic. Other studies should also explore continued inequities within technology access within Minority Serving Institutions.

\section{REFERENCES}

Ajzen, I. (1985). From intentions to actions: A theory of planned behavior. In J. K. Beckmann (Eds.), Action control: From cognition to behavior (pp. 11-39). Springer.

Ajzen, I. (1991). The theory of planned behavior. Organizational Behavior and Human Decision Processes, 50(2), 179-211.

Al-alak, B., \& Alnawas, I. A. (2011). Measuring the acceptance and adoption of elearning by academic staff. Knowledge Management and E-Learning, 3(2), 201. https://search.proquest.com/docview/1955103802 ?accountid

Anderson, M. (2017). A look at historically black colleges and universities as Howard turns 150. https://www.pewresearch.org/fact-tank/2017/02/28/alook-at-historically-black-colleges-and-universities-as-howard-turns-150/.

Arroyo, A.T., \& Gasman, M. (2014). An HBCU-based educational approach for black college student success: Toward a framework with implications for all institutions. American Journal of Education, 121(1), 57-85.

Beasley, R. (2014, July 10). HBCUs online and blended programs. HBCU-levers. https://hbcu-levers.blogspot.com/2014/07/hbcus-online-and-blendeddegree.html

Bourrie, D. M., Farmer, L, A. J., \& Sankar, C. S. (2016). Growing the intention to adopt educational innovations: An empirical study. Knowledge Management and E-Learning, 8(1), 22-38. https://search.proquest.com/docview/1955092465?accountid=12557.

Bracey, E. N. (2017). The significance of historically black colleges and Universities (HBCUs) in the $21^{\text {st }}$ century: Will such institutions of higher learning survive? American Journal of Economics \& Sociology, 76(3), 670 696. https://doiorg.proxyms.researchport.umd.edu/10.1111/ajes.12191

Broussard, L., \& Wilson, K. (2018). Nursing faculty attitudes and practices related to online teaching. Nursing Education Perspectives, 39(1), 40-42. http://dx.doi.org/10.1097/01.NEP.0000000000000208.

Chan, J.C. (1991). Response-order effects in Likert-type scales. Educational Psychology Measure, 51(3), 531-540.

Chen, B. (2009). Barriers to adoption of technology mediated online education in higher education institutions. Quarterly Review of Online Education, 10(4), 333-339.

https://search.proquest.com/docview/89232285?accountid=12557 
Christensen, R., \& Knezek, G. (1996). Constructing the teachers' attitudes toward computers (TAC) questionnaire.

https://files.eric.ed.gov/fulltext/EJ844212.pdf

Christensen, R., \& Knezek, G. (1997). Internal consistency reliabilities for 14 computer attitude scales. Best quantitative research studies award, society for technology in teacher education. In J. Willis, Price, Robin, McNeiland D. Willis (Eds.), Technology in Teacher Education Annual (pp. 877-880). AACE.

Creswell, J. W. (2018). Educational research: Planning, conducting and evaluating quantitative and qualitative research ( $5^{\text {th }} \mathrm{Ed}$.). Pearson.

Flowers, L.O., White, E.N., Raynor, Jr., J.E., \& Bhattacharya, S. (2012). African American students' participation in online education in STEM disciplines: Implications for HBCUs. Sage Open, 2012 pp 1-5.

Galvin, M. (2020.). SHARE historically black colleges and universities take center stage as the nation responds to COVID-19 and systemic racism. nationalacademies.org.

Gasman, M., Nguyen, T., Samayoa, A. C., Commodore, F., \& Hyde Carter, Y. (2013). The changing face of historically black colleges and universities. Philadelphia: Penn Center for Minority Serving Institutions. https://repository.upenn.edu/gse_pubs/335/

Glass, C. R. (2017). Self-expression, social roles and faculty member's attitudes toward online teaching. Innovative Higher Education, 42(3), 239-252. http://dx.doi.org/10.1007/s10755-016-9379-2

Grossman, A. M., \& Johnson, L. R. (2015). Faculty perceptions of online accounting coursework. American Journal of Business Education, 8(2), 95-106 https://search.proquest.com/docview/1673824269? accountid=12557.

Harkness, S. (2015). How a historically black college university (HBCU) established a sustainable online learning program in partnership with quality matters (TM). The American Journal of Online Education, 29(3), 198-209

https://search.proquest.com/docview/1717552771?accountid=12557

Hirt, J. B., Amelink, C. T., McFeeters, B. B., \& Strayhorn, T. L. (2008). A system of other mothering: Student affairs administrators' perceptions of relationship with students at historically Black colleges. NASPA Journal, 45(2), 210-236.

Hodge-Clark, K., \& Daniels, B. D. (2014). Top strategic issues facing HBCUs, now and into the future. Governing Boards of Universities.

Hurt, H. T., Joseph, K., \& Cook, C. D. (1977). Scales for the measurement of innovativeness. Human Communication Research, 4(1), 58-65. https:/www.sciencedirect.com/science/article/abs/pii/S07475632163059

Keesee, G. S., \& Shepard, M. (2011). Perceived attributes predict course management system adopter status. Online Journal of Online Learning Administration, 14(2), 1-24. 
Kopcha, T. J., Rieber, L. P., \& Walker, B. B. (2016). Understanding university faculty perceptions about innovation in teaching and technology. British Journal of Educational Technology, 47(5), 945-957. doi:10.1111/bjet.12361

Lawrence, J. (2008). The adoption and diffusion of computing and internet technologies in historically black colleges and universities. International Journal of Applied Management and Technology, 6(2), 88-112

Lee, J., March, L., \& Peters, R. (2015). Faculty training and approach to online learning: Is there a connection CTRL, 1-11 https://edspace.american.edu/online/wpontent/uploads/sites/504/2016/03/.

Lorenzetti, J. P. (2009). Attitudes toward online courses at HBCUs. Online Education Report, 13(12), 3-8.

McQuiggan C. A (2006). A survey of university faculty innovation concerns and perceptions influence the adoption and diffusion of a course management system. Paper presented at the Academy of Human Resource Development International (AHRD) Conference. 1160-

1167. http://www.eric.ed.gov/ERICDocs/data/ericdocs2sql /content_storage_01/0000019b/80/1b/e0/3d.pdf.

Mishra,S., \& Panda, S. (2007). Development and factor analysis of an instrument to measure student's attitude toward e-learning. Asian Journal of Online Education, 5(1), 27-33.

Mitchell, B.and Geva-May, I. (2009). Attitudes affecting online learning implementation in higher education institutions. Journal of Online Education (Online), 23(1), 71-88. https://search.proquest.com/docview/868055340?accountid=12557

Nealy, M. J. (2009). Pride and peril: Historically Black colleges and universities. Diverse Issues in Higher Education, 26(14), 18.

Online Report Card (2015). Tracking online education in the United States-OLC. (n.d.). http://onlinelearningconsortium.org/read/onlinereportcard- trackingonline-education-united-states-2015/.

Padmavathi, M. (2016). A study of student-teachers' readiness to use computers in teaching: An empirical study. I-Manager's. Journal on School Educational Technology, 11(3), 29-39.

Pallister, J. G., \& Foxall, G. R. (1998). Psychometric properties of the Hurt-JosephCook scales for the measurement of innovativeness. Technovation, 75(11), 663-675.

Pereira, A. S., \& Wahi, M. M. (2017). Strategic approaches to increase course management system adoption by higher education faculty. Journal of Higher Education Theory and Practice, 17(2), 61-69.

Poster, C. (2017). Job description of a tenure track assistant professor. Chron. https://work.chron.com/job-description tenure-track-assistant-professor18462.html. 
Rainer, J. K., \& Miller, M. D. (1996). An assessment of the psychometric properties of the computer attitude scale. Computers in Human Behavior, 1293-105. doi:10.1016/0747-5632(95) 00021-6.

Rogers, E. M. (2003). Diffusion of innovations ( $5^{\text {th }}$ Ed.). Free Press.

Samayoa, A. C., Nguyen, T., Gasman, M., Commodore, F., \& Abiola, U. (2016). Examining the potential of massive open online courses (MOOCs) at historically black colleges and universities (HBCUs). The Journal of Negro Education, 85(4), 480-488.

Smith,R., I. (2011). HBCUs must embrace online education. Diverse Issues in Higher Education, 28(3), 25-25.

Snipes, V. T., Ellis, W., \& Thomas, J. (2006). Are HBCUs up to speed technologically? One case study. Journal of Black Studies,36(3), 382-395. Doi: $10.1177 / 0021934705278782$.

Stuart, R., \& Yep, D. (2012). Survey: nearly one in four HBCUs offer full, blended online degree programs. Diverse Issues in Higher Education, 29(15), 1616.

Sturgis, I. (2012). The online frontier. Diverse Issues in Higher Education, 29(3), 16-19.

Waymer, D., \& Street, J. (2016). Second-class, cash strapped, antiquated institutions. Journal for Multicultural Education, 10(4), 489-506.

Wickersham, L. E., \& McElhany, J. A. (2010). Bridging the divide reconciling administrator and faculty concerns regarding online education. Quarterly Review of Online Education, 11(1), 1-12.

Zhang Z. (2016). Missing data imputation: focusing on single imputation. Ann Transl Med, 4(9). Doi: 10.21037/atm.2016.09.40.at all institutions, 2001/02-2012/13.

VALERIE RIGGS, EdD, is an assistant professor in the Department of Teacher Education and Professional Development at Morgan State University. Email: valierie.riggs@morgan.edu

KRISHNA BISTA, EdD, is a professor in the Department of Advanced Studies, Leadership and Policy at Morgan State University. Email: Krishna.bista@morgan.edu

CHRISTIAN ANDERSON, EdD is an assistant professor in the Department of Teacher Education and Professional Development at Morgan State University. Email: Christian.anderson@morgan.edu

Manuscript submitted: August 9, 2020 Manuscript revised: May 31, 2021 Accepted for publication: July 5, 2021 $-144-$ 
- 145 - 